\title{
Chryseobacterium ginsenosidimutans sp. nov., a bacterium with ginsenoside-converting activity isolated from soil of a Rhus vernicifera-cultivated field
}

Correspondence

Tae-Hoo Yi

drhoo@khu.ac.kr

Se-Young Kim

sekim@khu.ac.kr

\author{
Wan-Taek Im, Jung-Eun Yang, Se-Young Kim and Tae-Hoo Yi
}

Department of Oriental Medicinal Material and Processing College of Life Science, Kyung Hee
University, 1 Seocheon-dong, Kihung-gu Yongin-si, Kyunggi-do 449-701, Republic of Korea

\begin{abstract}
A Gram-reaction-negative, strictly aerobic, non-motile, non-spore-forming, rod-shaped bacterial strain, designated THG $15^{\top}$, was isolated from soil of a field cultivated with Rhus vernicifera in Okcheon province, South Korea, and its taxonomic position was investigated by using a polyphasic approach. Strain THG $15^{\mathrm{T}}$ grew optimally at $25-30{ }^{\circ} \mathrm{C}$ and at $\mathrm{pH}$ in the absence of $\mathrm{NaCl}$ on nutrient agar. Strain THG $15^{\top}$ displayed $\beta$-glucosidase (aesculinase) activity that was responsible for its ability to transform ginsenoside $\mathrm{Rb}_{1}$ (one of the dominant active components of ginseng) into compound $\mathrm{K}$ via $\mathrm{Rd}$ and $\mathrm{F}_{2}$. On the basis of $16 \mathrm{~S}$ rRNA gene sequence similarities, strain THG $15^{\mathrm{T}}$ was shown to belong to the family Flavobacteriaceae and was most closely related to Chryseobacterium soldanellicola PSD1-4 ${ }^{\top}$ (97.7\% sequence similarity), Chryseobacterium soli JS6-6 $6^{\top}$ (97.5\%) and Chryseobacterium indoltheticum LMG $4025^{\top}$ (97.3\%). The $\mathrm{G}+\mathrm{C}$ content of the genomic DNA was $35.7 \mathrm{~mol} \%$. The major menaquinone was MK-6 and the major fatty acids were iso- $\mathrm{C}_{15: 0}(50.3 \%)$, iso- $\mathrm{C}_{17: 0} 3-\mathrm{OH}(21.9 \%)$, summed feature 4 (comprising $\mathrm{C}_{16: 1} \omega 7 c$ and/or iso- $\left.\mathrm{C}_{15: 0} 2-\mathrm{OH} ; 9.5 \%\right)$ and iso- $\mathrm{C}_{17: 1} \omega 9 c$ (9.3\%). DNA sequence analysis and chemotaxonomic data supported the affiliation of strain THG $15^{\top}$ to the genus Chryseobacterium. DNA-DNA relatedness values between strain $\mathrm{THG}^{\mathrm{T}} 5^{\mathrm{T}}$ and its closest phylogenetic neighbours were $<15 \%$. Strain THG $15^{\top}$ could be differentiated genotypically and phenotypically from recognized species of the genus Chryseobacterium. The isolate therefore represents a novel species, for which the name Chryseobacterium ginsenosidimutans sp. nov. is proposed. The type strain is THG $15^{\top}\left(=\right.$ KACC $\left.14527^{\top}=J C M 16719^{\top}\right)$.
\end{abstract}

Ginseng (the root of Panax ginseng C. A. Meyer) is one of the most popular medicinal plants and it has been used for strengthening immunity, providing nutrition and recovering from fatigue. Ginseng saponins (ginsenosides) have been recognized as being active agents in the biological and pharmacological properties of ginseng (Choi, 2008). More than 40 different ginsenosides have been isolated from ginseng roots, six of which (ginsenosides $\mathrm{Rb}_{1}, \mathrm{Rb}_{2}, \mathrm{Rc}, \mathrm{Rd}$, $\operatorname{Re}$ and $\operatorname{Rg}_{1}$ ) constitute $>90 \%$ of the total ginsenosides (Park, 2004).

Biotransformation of ginsenosides can be achieved by hydrolysing and removing a sugar moiety using bacterial and fungal strains (Kim et al., 2005; Son et al., 2008; Zhao et al., 2009). Biotransformed ginsenoside compound $\mathrm{K}$ has attracted outstanding attention in recent years because of its anti-tumour (Chae et al., 2009), anti-inflammatory (Choi et al., 2007), anti-allergic (Shin \& Kim, 2005), anti-diabetic

The GenBank/EMBL/DDBJ accession number for the 16S rRNA gene sequence of strain THG $15^{\top}$ is GU138380.
(Kim et al., 2009) and hepato-protective effects (Lee et al., 2005).

The genus Chryseobacterium, created by Vandamme et al. (1994), is a member of the family Flavobacteriaceae, phylum 'Bacteroidetes' (Bernardet et al., 2006). At the time of writing, it consisted of 45 species with validly published names, with Chryseobacterium gleum as the type species (Euzéby, 1997). Many novel species of the genus Chryseobacterium have been described in recent years from a variety of clinical and environmental sources, such as Chryseobacterium anthropi (Kämpfer et al., 2009), Chryseobacterium piscicola (Ilardi et al., 2009), Chryseobacterium bovis (Hantsis-Zacharov et al., 2008) and Chryseobacterium hungaricum (Szoboszlay et al., 2008).

During the course of a study screening ginsenosideconverting aerobic bacterial strains in soil of a Rhus vernicifera-cultivated field in Okcheon province, South Korea, several novel bacterial strains were isolated. One strain, designated THG $15^{\mathrm{T}}$, which could convert ginsenoside 
$\mathrm{Rb}_{1}$ to compound $\mathrm{K}$ via $\mathrm{Rd}$ and $\mathrm{F}_{2}$, appeared to be a member of the genus Chryseobacterium and was subjected to a polyphasic taxonomy study. Here, the taxonomic characterization of strain THG $15^{\mathrm{T}}$ is reported.

The soil sample was thoroughly suspended in $50 \mathrm{mM}$ phosphate buffer ( $\mathrm{pH} 7$ ) and spread on modified R2A agar as described by Liu et al. (2006). The plates were incubated at $30{ }^{\circ} \mathrm{C}$ for 2 weeks. Single colonies were first transferred onto new modified R2A agar and then onto conventional R2A agar (BD) or nutrient agar (NA; BD). Strain THG $15^{\mathrm{T}}$ was cultured routinely on these media at $25^{\circ} \mathrm{C}$ and preserved as a suspension in nutrient broth $(\mathrm{NB} ; \mathrm{BD})$ with $20 \%(\mathrm{w} / \mathrm{v})$ glycerol at $-70{ }^{\circ} \mathrm{C}$.

Genomic DNA of strain THG $15^{\mathrm{T}}$ was extracted using a commercial genomic DNA-extraction kit (Solgent). The 16S rRNA gene was amplified from the chromosomal DNA using the universal bacterial primer pair $9 \mathrm{~F}$ and $1512 \mathrm{R}$ and the purified PCR products were sequenced by Solgent, Daejeon, South Korea (Ten et al., 2008). The almost complete sequence of the 16S rRNA gene was compiled using the software SeqMan (DNASTAR). The 16S rRNA gene sequences of related taxa were obtained from GenBank and from the EzTaxon server (http://www.eztaxon.org/; Chun et al., 2007). Multiple alignments were performed by using the program CLUSTAL_X (Thompson et al., 1997) and gaps were edited using the program BioEdit (Hall, 1999). Evolutionary distances were calculated using the Kimura two-parameter model (Kimura, 1983). Phylogenetic trees were constructed using the neighbour-joining (Saitou \& Nei, 1987) and maximum-parsimony (Fitch, 1971) methods in the program MEGA4 (Kumar et al., 2008) with bootstrap values based on 1000 replications (Felsenstein, 1985).

The 16S rRNA gene sequence of strain THG $15^{\mathrm{T}}$ determined in this study was a continuous stretch of 1386 bp (base positions 50-1458 with respect to the Escherichia coli numbering system). Sequence similarity calculations using the EzTaxon server indicated that the closest relatives of strain THG $15^{\mathrm{T}}$ were Chryseobacterium soldanellicola $\mathrm{PSD} 1-4^{\mathrm{T}} \quad(97.7 \%$ sequence similarity $)$, Chryseobacterium soli JS6-6 ${ }^{\mathrm{T}}(97.5 \%)$, Chryseobacterium gregarium $\mathrm{P} 461 / 12^{\mathrm{T}}$ (97.4\%), Chryseobacterium indoltheticum LMG $4025^{\mathrm{T}}$ (97.3\%), Chryseobacterium piscicola VQ$6316 \mathrm{~s}^{\mathrm{T}}(97.0 \%)$ and Chryseobacterium taiwanense BCRC $17412^{\mathrm{T}}(97.0 \%)$. Sequence similarities $<97.0 \%$ were found with all other recognized species of the genus Chryseobacterium. The relationship between strain THG $15^{\mathrm{T}}$ and members of the genus Chryseobacterium was also evident in the phylogenetic tree, which was based on the comparison of $1350 \mathrm{nt}$ sequences (Fig. 1). On the basis of the phylogenetic inference, C. soldanellicola PSD1-4 ${ }^{\mathrm{T}}$, C. soli JS6-6 ${ }^{\mathrm{T}}$, Chryseobacterium aquaticum 10-46 ${ }^{\mathrm{T}}$, Chryseobacterium scophthalmum LMG $13028^{\mathrm{T}}$ and Chryseobacterium piscium LMG $23089^{\mathrm{T}}$ were the closest neighbours of strain THG $15^{\mathrm{T}}$; these strains were obtained from culture collections, grown under the same conditions and used as reference strains in most phenotypic tests and in DNA-DNA hybridization experiments.

The Gram-reaction was performed by the non-staining method as described by Buck (1982). Cell morphology and motility were observed at $\times 1000$ magnification with a light microscope (BX50; Olympus) using cells grown for $24 \mathrm{~h}$ at $27{ }^{\circ} \mathrm{C}$ on NA. Catalase activity was assessed by bubble production in $3 \%(\mathrm{v} / \mathrm{v})$ hydrogen peroxide and oxidase activity was determined using $1 \%(\mathrm{w} / \mathrm{v})$ tetramethyl $p$ phenylenediamine. Carbon-source utilization and enzyme activities were tested by using API 20 NE, API ID 32 GN and API ZYM kits according to the manufacturer's instructions (bioMérieux). Tests for degradation of DNA [using DNASE agar (Scharlau) flooded with $1 \mathrm{M} \mathrm{HCl}$ to reveal DNase activity], casein (skimmed milk) and starch (Atlas, 1993) were evaluated after 7 days of incubation at $27{ }^{\circ} \mathrm{C}$. Growth was assessed after 5 days of incubation at 4 , $10,18,27,35,37,42$ and $45^{\circ} \mathrm{C}$ on NA and at pH 5-10 (at

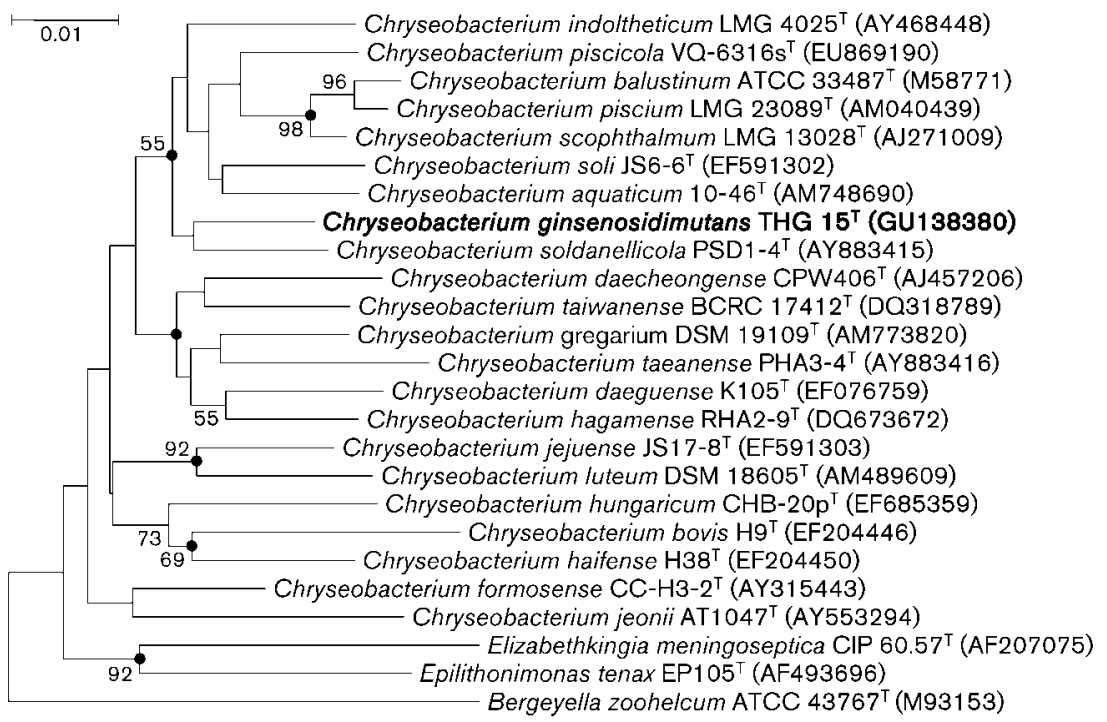

Fig. 1. Neighbour-joining phylogenetic tree based on 16S rRNA gene sequences showing the relationships of strain THG $15^{\top}$ to related species of the genus Chryseobacterium and representatives of related genera in the family Flavobacteriaceae. Filled circles at nodes indicate generic branches that were also recovered by using the maximum-parsimony algorithm. Bootstrap values $>70 \%$ (expressed as percentages of 1000 replications) are shown at branching points. Bar, 0.01 substitutions per nucleotide position. 
intervals of $0.5 \mathrm{pH}$ units) in NB. Three different buffers (50 $\mathrm{mM}$ final concentration) were used to adjust the $\mathrm{pH}$ of NB. Acetate buffer was used for $\mathrm{pH}$ 5.0-5.5, phosphate buffer was used for $\mathrm{pH}$ 6.0-8.0 and Tris buffer was used for $\mathrm{pH}$ 8.5-10.0. Salt tolerance was tested in NB supplemented with $1-10 \%(\mathrm{w} / \mathrm{v}) \mathrm{NaCl}$ (at intervals of $1 \%$ ) after 5 days of incubation. Growth was determined by monitoring $\mathrm{OD}_{600}$. Anaerobic growth was tested in serum bottles containing NB plus thioglycolate $\left(1 \mathrm{~g} \mathrm{l}^{-1}\right)$ and substituting the air atmosphere of the bottle with nitrogen gas. Growth was also evaluated on trypticase soy agar (TSA; BD), MacConkey agar (BD) and cetrimide agar (BD) at $27{ }^{\circ} \mathrm{C}$. The presence of flexirubin-type pigments was tested as described previously (Fautz \& Reichenbach, 1980) using 20\% (w/v) KOH. Conversion of ginsenoside $\mathrm{Rb}_{1}$ was assessed using TLC and HPLC analysis as described by Kim et al. (2005).

Cells of strain THG $15^{\mathrm{T}}$ were Gram-reaction-negative, strictly aerobic, non-spore-forming, non-motile, oxidase-positive and catalase-positive rods that produced flexirubin-type pigments. Activities of $\alpha$-and $\beta$-glucosidases were detected in strain THG $15^{\mathrm{T}}$; these enzymes are responsible for the gradual conversion of ginsenoside $\mathrm{Rb}_{1}$ to compound $\mathrm{K}$ (data not shown). The phenotypic characteristics of strain THG $15^{\mathrm{T}}$ and five reference type strains are summarized in the species description and given in Table 1.

The genomic DNA of strain THG $15^{\mathrm{T}}$ was extracted and purified as described by Moore \& Dowhan (1995) and its $\mathrm{G}+\mathrm{C}$ content was determined as described by Mesbah et al. (1989) using reversed-phase HPLC. The cellular fatty acid profiles of strain THG $15^{\mathrm{T}}$ and five reference type strains were determined using cells grown on NA for 2 days at $27{ }^{\circ} \mathrm{C}$. Cellular fatty acids were saponified, methylated and extracted according to the protocol of the Sherlock microbial identification system (MIDI) and analysed by capillary GLC (Hewlett Packard 6890) using the Microbial Identification software package with the Sherlock system MIDI 6.0 and the Sherlock Aerobic Bacterial Database (TSBA60) (Sasser, 1990). For isoprenoid quinone analysis,

Table 1. Differential characteristics of strain THG $15^{\top}$ and type strains of related species of the genus Chryseobacterium

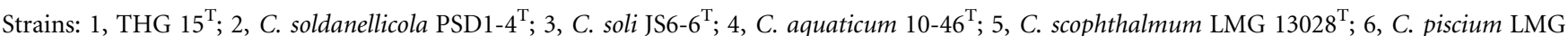
$23089^{\mathrm{T}}$. All data are from this study, except for the DNA G + C contents of the reference strains (taken from Park et al., 2006; Weon et al., 2008; Kim et al., 2008; Vandamme et al., 1994; de Beer et al., 2006). All strains were Gram-reaction-negative rods, catalase- and oxidase-positive and tolerate $1 \% \mathrm{NaCl}$. In API $20 \mathrm{NE}$ and API ID $32 \mathrm{GN}$ kits, all strains were positive for arginine dihydrolase and urease activities, gelatin and casein hydrolysis, production of flexirubin-type pigments and assimilation of D-glucose, maltose and D-mannose. All strains were negative for nitrate reduction, acid production from glucose and assimilation of the following substrates: 2-ketogluconate, 3-hydroxybenzoate, 3-hydroxybutyrate, 4hydroxybenzoate, 5-ketogluconate, adipate, caprate, citrate, D-mannitol, melibiose, D-ribose, D-sorbitol, gluconate, myo-inositol, itaconate, lactate, L-fucose, L-histidine, L-serine, malate, malonate, $N$-acetylglucosamine and suberate. In API ZYM kits, all strains were positive for alkaline phosphatase, leucine arylamidase, valine arylamidase, acid phosphatase, naphthol-AS-B1-phosphohydrolase, $\alpha$ - and $\beta$-glucosidase activities but negative for esterase (C4), lipase (C14), cystine arylamidase, $\alpha$-chymotrypsin, $\alpha$ - and $\beta$-galactosidase, $\beta$-glucuronidase, $\alpha$-mannosidase and $\alpha$ fucosidase. + , Positive; - , negative; $\mathrm{w}$, weakly positive.

\begin{tabular}{|c|c|c|c|c|c|c|}
\hline Characteristic & 1 & 2 & 3 & 4 & 5 & 6 \\
\hline Indole production & - & + & + & - & + & + \\
\hline \multicolumn{7}{|l|}{ Hydrolysis of: } \\
\hline DNA & + & - & + & + & + & - \\
\hline Starch & + & + & + & + & - & - \\
\hline \multicolumn{7}{|c|}{ Assimilation of (API 20NE/API ID 32 GN): } \\
\hline Acetate & + & + & + & + & - & - \\
\hline Sucrose & - & + & - & + & + & - \\
\hline Glycogen & + & + & - & + & + & + \\
\hline L-Alanine & + & + & - & - & - & + \\
\hline L-Arabinose & + & + & - & - & + & - \\
\hline L-Proline & + & - & - & - & + & + \\
\hline L-Rhamnose & - & + & + & - & + & - \\
\hline Phenylacetate & - & - & - & - & - & + \\
\hline Propionate & + & - & + & + & - & + \\
\hline Salicin & - & - & - & - & + & - \\
\hline Valerate & + & - & - & - & - & + \\
\hline \multicolumn{7}{|l|}{ Enzyme activity (API ZYM) } \\
\hline Esterase lipase (C8) & $\mathrm{W}$ & + & $\mathrm{W}$ & $\mathrm{w}$ & $\mathrm{W}$ & $\mathrm{W}$ \\
\hline Trypsin & - & - & + & + & + & + \\
\hline$N$-Acetyl- $\beta$-glucosaminidase & + & - & - & - & + & - \\
\hline DNA G + C content $(\mathrm{mol} \%)$ & 35.7 & 29 & 39.9 & 38.5 & 34.1 & 34 \\
\hline
\end{tabular}


strain THG $15^{\mathrm{T}}$ was grown in modified NB for 2 days at $27{ }^{\circ} \mathrm{C}$. Cells were lyophilized for $24 \mathrm{~h}$ and isoprenoid quinones were extracted with chloroform/methanol $(2: 1$, $\mathrm{v} / \mathrm{v})$, evaporated under vacuum and re-extracted in $\mathrm{n}$ hexane/water $(1: 1, \mathrm{v} / \mathrm{v})$. The crude $\mathrm{n}$-hexane/quinone solution was purified using Sep-Pak Vac silica cartridges (Waters) and subsequently analysed by HPLC as described previously (Hiraishi et al., 1996). DNA-DNA hybridization experiments were performed between strain THG $15^{\mathrm{T}}, C$. soli JS6- $6^{\mathrm{T}}$ and C. soldanellicola PSD1-4 ${ }^{\mathrm{T}}$ according to the method described by Ezaki et al. (1989) using photobiotinlabelled DNA probes and micro-dilution wells. Hybridization was performed at $39{ }^{\circ} \mathrm{C}$ with five replications for each sample. The highest and lowest values obtained for each sample were excluded and the means of the remaining three values were converted to DNA-DNA relatedness values (\%).

The DNA G + C content of strain THG $15^{\mathrm{T}}$ was $35.7 \mathrm{~mol} \%$, a value within the range reported for species of the genus Chryseobacterium (Bernardet et al., 2006). The major respiratory quinone of strain THG $15^{\mathrm{T}}$ was MK-6, which is in line with all other known members of the family Flavobacteriaceae (Bernardet \& Nakagawa, 2006). The fatty acid profiles of strain THG $15^{\mathrm{T}}$ and the five reference strains are shown in Table 2 . The fatty acid profile of strain THG $15^{\mathrm{T}}$ was mainly composed of iso- $\mathrm{C}_{15: 0}(50.3 \%)$, iso- $\mathrm{C}_{17: 0} 3-\mathrm{OH}$ $(21.9 \%)$, summed feature 4 (comprising $\mathrm{C}_{16: 1} \omega 7 c$ and/or iso- $\left.\mathrm{C}_{15: 0} 2-\mathrm{OH} ; 9.5 \%\right)$ and iso- $\mathrm{C}_{17: 1} \omega 9 c(9.3 \%)$, which is similar to the profiles of its five closest relatives. DNA-DNA relatedness values of strain THG $15^{\mathrm{T}}$ with $C$. soli JS6- $6^{\mathrm{T}}$ and C. soldanellicola PSD $1-4^{\mathrm{T}}$ were 12 and $15 \%$, respectively.

In summary, the characteristics of strain THG $15^{\mathrm{T}}$ were consistent with those of members of the genus
Chryseobacterium with regard to morphological, biochemical and chemotaxonomic properties. However, the phylogenetic distance and the low DNA-DNA relatedness values (Wayne et al., 1987) between strain THG $15^{\mathrm{T}}$ and recognized species of the genus Chryseobacterium along with its unique phenotypic characteristics (Table 1) suggests strain THG $15^{\mathrm{T}}$ represents a novel species of the genus Chryseobacterium, for which the name Chryseobacterium ginsenosidimutans sp. nov. is proposed.

\section{Description of Chryseobacterium ginsenosidimutans sp. nov.}

Chryseobacterium ginsenosidimutans (gin.se.no.si.di.mu'tans. N.L. n. ginsenosidum ginsenoside; L. part. adj. mutans transforming, converting; N.L. part. adj. ginsenosidimutans ginsenoside-converting).

Cells are Gram-reaction-negative, strictly aerobic, nonmotile and non-spore-forming rods, $0.3-0.5 \times 1.5-2.0 \mu \mathrm{m}$ after culture on NA for 2 days. Colonies are smooth, transparent, deep-orange, convex, circular with regular margins and $1.0-1.5 \mathrm{~mm}$ in diameter after 2 days of growth on NA. Growth also occurs on TSA and R2A agar but not on MacConkey or cetrimide agars. Growth occurs on NA at $10-37{ }^{\circ} \mathrm{C}$ and $\mathrm{pH} 5.5-10.0$ but not at $4{ }^{\circ} \mathrm{C}$ or $42{ }^{\circ} \mathrm{C}$. Optimum growth occurs at $25-30{ }^{\circ} \mathrm{C}$ and $\mathrm{pH}$ 7.0. Growth occurs in the absence of $\mathrm{NaCl}$ and in the presence of $1.0 \%(\mathrm{w} / \mathrm{v}) \mathrm{NaCl}$ but not with $2.0 \%(\mathrm{w} / \mathrm{v}) \mathrm{NaCl}$. Catalase- and oxidase-positive. Starch, gelatin, casein and DNA are hydrolysed. Flexirubin-type pigments are produced. Arginine dihydrolase and urease activities are present. Nitrate is not reduced. Acid is not produced from glucose. The substrates utilized as sole carbon sources (API ID $32 \mathrm{GN}$, API $20 \mathrm{NE}$ ) and the enzyme activities (API

Table 2. Cellular fatty acid profiles (\%) of strain THG $15^{\top}$ and phylogenetically related species of the genus Chryseobacterium

Strains: 1, THG $15^{\mathrm{T}}$; 2, C. soldanellicola PSD1-4 ${ }^{\mathrm{T}} ; 3$, C. soli JS6-6 ${ }^{\mathrm{T}}$; 4, C. aquaticum 10-46 ${ }^{\mathrm{T}} ; 5$, C. scophthalmum $\mathrm{LMG} 13028^{\mathrm{T}}$; 6, C. piscium $\mathrm{LMG}$ $23089^{\mathrm{T}}$. All data are from this study. All strains were cultured on NA for 2 days at $27^{\circ} \mathrm{C}$. Fatty acids amounting to $<1 \%$ of the total fatty acids in all strains are not listed. - , Not detected.

\begin{tabular}{|c|c|c|c|c|c|c|}
\hline Fatty acid & 1 & 2 & 3 & 4 & 5 & 6 \\
\hline \multicolumn{7}{|l|}{ Saturated } \\
\hline $\mathrm{C}_{16: 0}$ & - & - & - & 6.5 & - & - \\
\hline \multicolumn{7}{|l|}{ Branched-chain } \\
\hline iso- $\mathrm{C}_{13: 0}$ & - & - & - & 2.7 & - & - \\
\hline iso- $C_{15: 0}$ & 50.3 & 47.8 & 42.2 & 48.3 & 44.4 & 47.3 \\
\hline iso- $\mathrm{C}_{17: 1} \omega 9 c$ & 9.3 & 13.6 & 14.3 & - & 20.1 & 17.0 \\
\hline anteiso- $\mathrm{C}_{15: 0}$ & 3.8 & 5.0 & 8.1 & 5.4 & 3.2 & 4.5 \\
\hline \multicolumn{7}{|l|}{ Hydroxy } \\
\hline iso- $\mathrm{C}_{15: 0} 3-\mathrm{OH}$ & 5.2 & 4.1 & 4.3 & 3.9 & 4.7 & 5.4 \\
\hline iso- $\mathrm{C}_{16: 0} 3-\mathrm{OH}$ & - & - & - & 4.7 & - & - \\
\hline iso- $\mathrm{C}_{17: 0} 3-\mathrm{OH}$ & 21.9 & 19.9 & 20.8 & 16.9 & 17.6 & 20.0 \\
\hline Summed feature $4^{*}$ & 9.5 & 9.7 & 10.4 & 11.6 & 10.1 & 5.9 \\
\hline
\end{tabular}

${ }^{\star}$ Summed features represent groups of two or three fatty acids that cannot be separated by GLC with the MIDI system. Summed feature 4 comprises $\mathrm{C}_{16: 1} \omega 7 c$ and/or iso- $\mathrm{C}_{15: 0} 2-\mathrm{OH}$. 
ZYM) are listed in Table 1. MK-6 is the predominant respiratory quinone. Major cellular fatty acids $(>9 \%)$ are iso- $\mathrm{C}_{15: 0}$, iso- $\mathrm{C}_{17: 0} 3-\mathrm{OH}$, summed feature 4 (comprising $\mathrm{C}_{16: 1} \omega 7 c$ and/or iso- $\left.\mathrm{C}_{15: 0} 2-\mathrm{OH}\right)$ and iso- $\mathrm{C}_{17: 1} \omega 9 c$.

The type strain is THG $15^{\mathrm{T}}$ (=KACC $14527^{\mathrm{T}}=\mathrm{JCM}$ $16719^{\mathrm{T}}$ ), isolated from soil of a Rhus vernicifera-cultivated field in Okcheon province, South Korea. The genomic DNA G $+\mathrm{C}$ content of the type strain is $35.7 \mathrm{~mol} \%$.

\section{Acknowledgements}

This work was supported by the 2010 research program of Rural Development Administration (PJ0070902009) and a grant from the Kyung Hee University in 2010 (20100177), Republic of Korea.

\section{References}

Atlas, R. M. (1993). Handbook of Microbiological Media. Edited by L. C. Parks. Boca Raton, FL: CRC Press.

Bernardet, J. F. \& Nakagawa, Y. (2006). An introduction to the family Flavobacteriaceae. In The Prokaryotes: a Handbook on the Biology of Bacteria, 3rd edn, vol. 7, pp. 455-480. Edited by M. Dworkin, S. Falkow, E. Rosenberg, K. H. Schleifer \& E. Stackebrandt. New York: Springer.

Bernardet, J.-F., Hugo, C. \& Bruun, B. (2006). The genera Chryseobacterium and Elizabethkingia. In The Prokaryotes: a Handbook on the Biology of Bacteria, 3rd edn, vol. 7, pp. 638-676. Edited by M. Dworkin, S. Falkow, E. Rosenberg, K. H. Schleifer \& E. Stackebrandt. New York: Springer.

Buck, J. D. (1982). Nonstaining (KOH) method for determination of Gram reactions of marine bacteria. Appl Environ Microbiol 44, 992993.

Chae, S., Kang, K. A., Chang, W. Y., Kim, M. J., Lee, S. J., Lee, Y. S., Kim, H. S., Kim, D. H. \& Hyun, J. W. (2009). Effect of compound K, a metabolite of ginseng saponin, combined with gamma-ray radiation in human lung cancer cells in vitro and in vivo. J Agric Food Chem 57, $5777-5782$.

Choi, K.-T. (2008). Botanical characteristics, pharmacological effects and medicinal components of Korean Panax ginseng C A Meyer. Acta Pharmacol Sin 29, 1109-1118.

Choi, K., Kim, M., Ryu, J. \& Choi, C. (2007). Ginsenosides compound $\mathrm{K}$ and $\mathrm{Rh}_{2}$ inhibit tumor necrosis factor-alpha-induced activation of the NF-kappaB and JNK pathways in human astroglial cells. Neurosci Lett 421, 37-41.

Chun, J., Lee, J.-H., Jung, Y., Kim, M., Kim, S., Kim, B. K. \& Lim, Y. W. (2007). EzTaxon: a web-based tool for the identification of prokaryotes based on 16S ribosomal RNA gene sequences. Int J Syst Evol Microbiol 57, 2259-2261.

de Beer, H., Hugo, C. J., Jooste, P. J., Vancanneyt, M., Coenye, T. \& Vandamme, P. (2006). Chryseobacterium piscium sp. nov., isolated from fish of the South Atlantic Ocean off South Africa. Int J Syst Evol Microbiol 56, 1317-1322.

Euzéby, J. P. (1997). List of bacterial names with standing in nomenclature: a folder available on the Internet. Int J Syst Bacteriol 47, 590-592. http://www.bacterio.cict.fr

Ezaki, T., Hashimoto, Y. \& Yabuuchi, E. (1989). Fluorometric deoxyribonucleic acid-deoxyribonucleic acid hybridization in microdilution wells as an alternative to membrane filter hybridization in which radioisotopes are used to determine genetic relatedness among bacterial strains. Int J Syst Bacteriol 39, 224-229.
Fautz, E. \& Reichenbach, H. (1980). A simple test for flexirubin-type pigments. FEMS Microbiol Lett 8, 87-91.

Felsenstein, J. (1985). Confidence limits on phylogenies: an approach using the bootstrap. Evolution 39, 783-791.

Fitch, W. M. (1971). Toward defining the course of evolution: minimum change for a specific tree topology. Syst Zool 20, 406-416.

Hall, T. A. (1999). BioEdit: a user-friendly biological sequence alignment editor and analysis program for Windows 95/98/NT. Nucleic Acids Symp Ser 41, 95-98.

Hantsis-Zacharov, E., Senderovich, Y. \& Halpern, M. (2008). Chryseobacterium bovis sp. nov., isolated from raw cow's milk. Int $J$ Syst Evol Microbiol 58, 1024-1028.

Hiraishi, A., Ueda, Y., Ishihara, J. \& Mori, T. (1996). Comparative lipoquinone analysis of influent sewage and activated sludge by highperformance liquid chromatography and photodiode array detection. J Gen Appl Microbiol 42, 457-469.

llardi, P., Fernández, J. \& Avendaño-Herrera, R. (2009). Chryseobacterium piscicola sp. nov., isolated from diseased salmonid fish. Int J Syst Evol Microbiol 59, 3001-3005.

Kämpfer, P., Vaneechoutte, M., Lodders, N., De Baere, T., Avesani, V., Janssens, M., Busse, H.-J. \& Wauters, G. (2009). Description of Chryseobacterium anthropi sp. nov. to accommodate clinical isolates biochemically similar to Kaistella koreensis and Chryseobacterium haifense, proposal to reclassify Kaistella koreensis as Chryseobacterium koreense comb. nov. and emended description of the genus Chryseobacterium. Int J Syst Evol Microbiol 59, 2421-2428.

Kim, M.-K., Lee, J.-W., Lee, K.-Y. \& Yang, D.-C. (2005). Microbial conversion of major ginsenoside $\mathrm{Rb}_{1}$ to pharmaceutically active minor ginsenoside Rd. J Microbiol 43, 456-462.

Kim, K. K., Lee, K. C., Oh, H. M. \& Lee, J. S. (2008). Chryseobacterium aquaticum sp. nov., isolated from a water reservoir. Int J Syst Evol Microbiol 58, 533-537.

Kim, Y., Yuan, H. D., Chung, I. K. \& Chung, S. H. (2009). Compound $\mathrm{K}$, intestinal metabolite of ginsenoside, attenuates hepatic lipid accumulation via AMPK activation in human hepatoma cells. J Agric Food Chem 57, 1532-1537.

Kimura, M. (1983). The Neutral Theory of Molecular Evolution. Cambridge: Cambridge University Press.

Kumar, S., Nei, M., Dudley, J. \& Tamura, K. (2008). MEGA: a biologistcentric software for evolutionary analysis of DNA and protein sequences. Brief Bioinform 9, 299-306.

Lee, H. U., Bae, E. A., Han, M. J., Kim, N. J. \& Kim, D. H. (2005). Hepatoprotective effect of ginsenoside $\mathrm{Rb}_{1}$ and compound $\mathrm{K}$ on tertbutyl hydroperoxide-induced liver injury. Liver Int 25, 1069-1073.

Liu, Q.-M., Im, W.-T., Lee, M., Yang, D.-C. \& Lee, S.-T. (2006). Dyadobacter ginsengisoli sp. nov., isolated from soil of a ginseng field. Int J Syst Evol Microbiol 56, 1939-1944.

Mesbah, M., Premachandran, U. \& Whitman, W. B. (1989). Precise measurement of the $\mathrm{G}+\mathrm{C}$ content of deoxyribonucleic acid by highperformance liquid chromatography. Int J Syst Bacteriol 39, 159167.

Moore, D. D. \& Dowhan, D. (1995). Preparation and analysis of DNA. In Current Protocols in Molecular Biology, pp. 2-11. Edited by F. M. Ausubel, R. Brent, R. E. Kingston, D. D. Moore, J. G. Seidman, J. A. Smith \& K. Struhl. New York: Wiley.

Park, J. H. (2004). Sun ginseng - a new processed ginseng with fortified activity. Food Ind Nutr 9, 23-27.

Park, M. S., Jung, S. R., Lee, K. H., Lee, M. S., Do, J. O., Kim, S. B. \& Bae, K. S. (2006). Chryseobacterium soldanellicola sp. nov. and Chryseobacterium taeanense sp. nov., isolated from roots of sand-dune plants. Int J Syst Evol Microbiol 56, 433-438. 
Saitou, N. \& Nei, M. (1987). The neighbor-joining method: a new method for reconstructing phylogenetic trees. Mol Biol Evol 4, 406-425.

Sasser, M. (1990). Identification of bacteria by gas chromatography of cellular fatty acids, MIDI Technical Note 101. Newark, DE: MIDI Inc.

Shin, Y. W. \& Kim, D. H. (2005). Antipruritic effect of ginsenoside $\mathrm{Rb}_{1}$ and compound $\mathrm{K}$ in scratching behavior mouse models. J Pharmacol Sci $99,83-88$.

Son, J.-W., Kim, H.-J. \& Oh, D.-K. (2008). Ginsenoside Rd production from the major ginsenoside $\mathrm{Rb}_{1}$ by $\beta$-glucosidase from Thermus caldophilus. Biotechnol Lett 30, 713-716.

Szoboszlay, S., Atzél, B., Kukolya, J., Tóth, E. M., Márialigeti, K., Schumann, P. \& Kriszt, B. (2008). Chryseobacterium hungaricum sp. nov., isolated from hydrocarbon-contaminated soil. Int J Syst Evol Microbiol 58, 2748-2754.

Ten, L. N., Jung, H.-M., Im, W. T., Yoo, S. A. \& Lee, S.-T. (2008). Lysobacter daecheongensis sp. nov., isolated from sediment of stream near the Daechung dam in South Korea. J Microbiol 46, 519-524.

Thompson, J. D., Gibson, T. J., Plewniak, F., Jeanmougin, F. \& Higgins, D. G. (1997). The CLUSTAL_X windows interface: flexible strategies for multiple sequence alignment aided by quality analysis tools. Nucleic Acids Res 25, 4876-4882.

Vandamme, P., Bernardet, J.-F., Segers, P., Kersters, K. \& Holmes, B. (1994). New perspectives in the classification of the flavobacteria: description of Chryseobacterium gen. nov., Bergeyella gen. nov., and Empedobacter nom. rev. Int J Syst Bacteriol 44, 827-831.

Wayne, L. G., Brenner, D. J., Colwell, R. R., Grimont, P. A. D., Kandler, O., Krichevsky, M. I., Moore, L. H., Moore, W. E. C., Murray, R. G. E. \& other authors (1987). International Committee on Systematic Bacteriology. Report of the ad hoc committee on reconciliation of approaches to bacterial systematics. Int J Syst Bacteriol 37, 463-464.

Weon, H. Y., Kim, B. Y., Yoo, S. H., Kwon, S. W., Stackebrandt, E. \& Go, S. J. (2008). Chryseobacterium soli sp. nov. and Chryseobacterium jejuense sp. nov., isolated from soil samples from Jeju, Korea. Int J Syst Evol Microbiol 58, 470-473.

Zhao, X., Wang, J., Li, J., Fu, L., Gao, J., Du, X., Bi, H., Zhou, Y. \& Tai, G. (2009). Highly selective biotransformation of ginsenoside $\mathrm{Rb}_{1}$ to $\mathrm{Rd}$ by the phytopathogenic fungus Cladosporium fulvum (syn. Fulvia fulva). J Ind Microbiol Biotechnol 36, 721-726. 